\title{
CONTROLE DA VITRIFICAÇÃO DO CRAVO (Dianthus caryophyllus L.) IN VITRO
}

\author{
G.R.F. CUZZUOL ${ }^{1}$; L.A. GALLO'; M. DE ALMEIDA ${ }^{2}$; O.J. CROCOMO' \\ ${ }^{1}$ Centro de Biotecnologia Agrícola-CEBTEC/Dept. de Química-ESALQ/USP, CEP: 13418-900,Piracicaba, SP \\ ${ }^{2}$ Dept. de Botânica - ESALQ/USP, CEP: 13418-900, Piracicaba, SP
}

\begin{abstract}
RESUMO - Baixos níveis de benziladenina (BAP), baixo potencial de agua no meio e baixa umidade condicionada por tampas de algodāo foram capazes de inibir a vitrificação de cravo (Dianthus caryophyllus L.) cultivado in vilro, mas essas condições implicaram no baixo desenvolvimento das plantas e da taxa de propagaçāo. Elevados níveis de $\mathrm{NH}_{4} \mathrm{NO}_{3}$ demonstraram serem altamente promotores da vitrificação assinalada pelo alto conteúdo de proteína, enquanto relação inversa foi constatada para altos níveis de $\mathrm{CaCl}_{2}$, aos quais seguiu-se aumento na atividade da peroxidase. Os resultados permitiram estabelecer um protocolo para controle da vitrificação do cravo, constituído de 4,0 g/1 de "Gelrite", $0,5 \mathrm{mg} / 1$ de ácido naftalenoacético (ANA), 0,05 mg/l de BAP, doses normais das soluções salinas do meio MS e vedação do tipo tampas de algodão para cultivo de ápices meristemáticos. Para a fase de

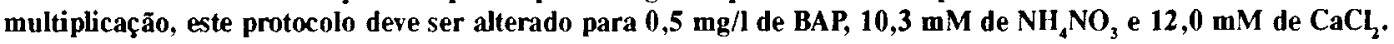
Descritores: cravo, Dianthus caryophyllus, vitrificação, meristema, micropropagação
\end{abstract}

\section{CONTROL, OF CARNATION VITRIFICATION \\ (Dianthus caryophyllus L.) IN VITRO}

\begin{abstract}
Low levels of benzyl adenine (BAP), low water potential of the growth medium and low humidity due to cotton covers, inhibited vitrification of carnation (Dianthus caryophyllus L.) in vitro. However, under these conditions, a low development of plants and a decrease in the multiplication ratio. were observed. High levels of amonium nitrate enhanced vitrification with an increase in the total soluble protein content. An inverse correlation was observed in the presence of high levels of calcium chloride. The latter was correlated to an increase in peroxidase activity. The results allowed the establishment of a protocol to control vitrification during carnation meristem growth, as follows: "Gelrite", $4 \mathrm{~g} / \mathrm{l}$; naphtalene acetic acid, $0.5 \mathrm{mg} / \mathrm{l}$; BAP, $0.05 \mathrm{mg} / \mathrm{l}$; normal dosis of MS salts; cotton covers. For in vitro multiplication the protocol should be altered to $\mathrm{BAP}, 0.5 \mathrm{mg} / \mathrm{l}$; amonium nitrate 10.3 $\mathrm{mM}$; calcium chloride $12.0 \mathrm{mM}$.
\end{abstract}

Key words: Dianthus caryophyllus, meristem, vitrification, carnation, micropropagation

\section{INTRODUÇÃO}

Algumas espécies, como o cravo (Dianthus caryophyllus L.), quando cultivadas in vitro são suscetíveis a uma reação de hipersensibilidade às condições de estresse do meio, desenvolvendo variações anormais como a vitrificação assinalada por desordens fisiológicas generalizadas (ZIV, 1991).

Plantas vitrificadas são caracterizadas por apresentarem baixos niveis de lignina e celulose (KEVERS el al., 1984; 1987); baixa resistência de parede celular (KEVERS \& GASPAR, 1986); hipertrofia celular (VIEITEZ et al., 1985); folhas entumescidas e quebradiças (DEBERGH, 1983; LESEHEM et al., 1988a,b; ZIV et al., 1987) $\mathrm{e}$ reduzida taxa de sobrevivência $\mathrm{cm}$ condições autotróficas (SUTTER \& LANGHANS, 1979).

A vitrificação é uma das principais anomalias que tem recebido atenção especial nos últimos anos, tendo sido observada a interação simultânea de diversos fatores, interferindo nas principais vias metabólicas como fotossíntese, respiração e transpiração (ZIV, 1991). Uma relação entre a vitrificação e a atividade de determinadas enzimas foi diagnosticada (PHAN \& LETOUZÉ, 1986). Em material vitrificado observa-se diminuição na atividade das enzimas peroxidase e CoA-ligase em relação à planta normal.

Os eventuais fatores da vitrificação têm sido atribuídos ao potencial osmótico (DEBERGH el al., 1981; HAKKAART \& 
VERSLUIJS, 1983; PASQUALETO et al., 1988), concentração dos reguladores de crescimento, especialmente a citocinina (LESHEM et al., 1988a; 1988b), umidade e a concentração salina do meio de cultura (DAGUIN \& LETOUZE, 1986). Para contribuir ao estudo dessa questão é que foi conduzido o presente trabalho tendo em vista determinar as condições controladoras da vitrificação do cravo in vitro.

\section{MATERIAL E MÉTODOS}

Efeito de benziladenina (BAP) - Ápices meristemáticos de cravo medindo aproximadamente $0,3 \mathrm{~mm}$ ( 1 ou 2 pares de primórdios foliares) foram inoculados em meio de MURASHIGE \& SKOOG, (1962) (meio MS), $8 \mathrm{~g} / 1$ de ágar; $30 \mathrm{~g} / 1$ de sacarose com pH ajustado a 5,5 e incubado em sala de crescimento com intensidade luminosa de 2000 lux, fotoperíodo de $12 \mathrm{~h}$ e temperatura de $25^{\circ} \mathrm{C}$. $\mathrm{O}$ meio de cultura básico foi suplementado com seis concentrações de BAP: 0,$0 ; 0,2 ; 0,4 ; 0,6 ; 0,8$ e $1,0 \mathrm{mg} / 1$, tendo 20 repetições por tratamento. Foram avaliadas a frequêencia de plantas vitrificadas e a performance do desenvolvimento das plantas após 40 dias da inoculação, obedecendo a um critério de notas com valores de 0 a 7 atribuído às características morfológicas. $O$ delineamento foi inteiramente casualizado.

Explantes nodulares medindo $1,5 \mathrm{~cm}$ de comprimento oriundos das plantas regeneradas a partir de ápices meristemáticos foram transferidos para meio básico MS acrescentado de BAP em seis concentrações: 0,$0 ; 0,1 ; 0,3 ; 0,5 ; 1,0$ e $2,0 \mathrm{mg} / \mathrm{l}$, incubados na mesma condição descrita para ápices meristemáticos. As variáveis analisadas foram o número e comprimento de brotações adventícias por explante e a freqüência da vitrificação.

Efeito do agente gelificante - Ápices meristemáticos foram inoculados em cinco concentrações do agente gelificante "Gelrite" :2,3; 2,7; 3,2; 3,8 e 4,5 g/l em meio básico de MS suplementado com $0,5 \mathrm{mg} / 1$ de ácido naftalenoacético (ANA) mais $0,05 \mathrm{mg} / 1$ de BAP. 0 experimento foi constituído de 10 repetições e o critério de avaliação foi o mesmo adotado para o efeito de BAP. Testa ram-se também cinco concentrações de "Gelrite": 2,5; 3,0; 4,0; 6,0 e $9,0 \mathrm{~g} / 1$ para explantes nodulares em meio de MS suplementado com $0,5 \mathrm{mg} / \mathrm{l}$ de BAP, com 10 repetições por tratamento. Foram avaliados o número e comprimento de brotações adventícias por explante e a freqüência de plantas vitrificadas.

Efeito do sistema de vedação - Este experimento em fatorial do tipo $2 \times 2$, constituiu-se de duas concentrações de ágar: 8 e $12 \mathrm{~g} / \mathrm{l}$ combinadas com dois tipos de vedação dos frascos: papel alumínio e tampas de algodão para regeneração de ápices meristemáticos. $O$ meio básico foi suplementado com 0,5 mg/l de ANA e 0,05 mg/l de BAP, com 10 repetições por tratamento. $O$ critério de avaliação foi o mesmo adotado para o efeito de BAP. Para os explantes nodulares testaram-se os dois tipos de vedação já citados combinados com 11 g/l de ágar e 4,5 g/l de "Gelrite". O meio básico foi suplementado com $0,5 \mathrm{mg} / 1$ de BAP, $10,3 \mathrm{mM}$ de $\mathrm{NH}_{4} \mathrm{NO}_{3}$ e $12,0 \mathrm{mM}$ de $\mathrm{CaCl}_{2}$. As variáveis analisadas foram o número e comprimento de brotações adventícias por explante e a freqüência da vitrificação.

Determinação do potencial de água - Adotou-se o método da higrometria de par termoelétrico, pelo uso de câmaras de amostras modelo C-52 e microvoltímetro higrométrico modelo HR-33, da Wescar Inc. As medidas foram realizadas após um tempo mínimo de 2 horas de equilíbrio das amostras nas câmaras. Mediu-se o potencial de água do meio básico tendo como agente solidificante "Gelrite" nas concentrações de 2,$5 ; 3,0 ; 4,0 ; 6,0$ e $9,0 \mathrm{~g} / \mathrm{l} \mathrm{e}$ da folha e região nodal de plantas normais $e$ vitrificadas.

Análise histologica - $O$ material foi cortado à mão livre, desidratado em série alcoólica, corado com vermelho congo e verde iôdo (SASS, 1951) e montado em lâminas histológicas semi permanentes.

Níveis de $\mathrm{NH}_{4} \mathrm{NO}_{3}$ e CaCl na taxa de vitrificacão -Explantes da regiẫo nodal medindo aproximadamente $1,5 \mathrm{~cm}$ de comprimento de plantas de cravo mantidas in vitro por um ano foram transferidos para meio básico semi-sólido de MS constituído de quatro concentrações de $\mathrm{NH}_{4} \mathrm{NO}_{3}$ : 0,$0 ; 20,6 ; 61,8$ e 130,0 mM e quatro concentrações de $\mathrm{CaCl}_{2}: 0,0 ; 3,0 ; 9,0$ e $15,0 \mathrm{mM}$ suplementado com $0,5 \mathrm{mg} / 1$ de BAP e 4,2 g/l de "Gelrite". Cada tratamento constou de 10 repetições, condicionadas 
em frascos vedados com tampas de algodão. A variável analisada foi a frequeência de plantas vitrificadas apos $\mathbf{3 0}$ dias de cultivo.

Determinação de proteína total solúvel - Para o material vegetal obtido dos tratamentos de diferentes niveis de fontes nitrogenadas e de cálcio na vitrificação, determinou-se o teor de proteína total solúvel (LOWRY et al., 1951) aos $\mathbf{3 0}$ dias após a inoculação.

Atividade de peroxidase - Extratos de plantas submetidas a vários níveis de fontes nitrogenadas e de cálcio foram obtidos utilizando tampão fosfato de sódio, pH 6,1 a 0,1 M na proporção 1:5. A mistura reativa se constituiu de $0,25 \mathrm{ml}$ de água oxigenada $0,1 \mathrm{M} ; 0,5 \mathrm{ml}$ de piroga lol $0,02 \mathrm{M}$ como doador de hidrogênio; $1,0 \mathrm{ml}$ de extrato diluído em 1:40; o volume foi completado a $3 \mathrm{ml} \mathrm{com}$ solução tampão. $O$ controle foi formado por todos os reagentes com exceção da água oxigenada. A análise foi realizada de acordo com FERHRMANN \& DIMON (1967), lendo-se a $470 \mathrm{~nm}$ no espectrofotômetro U-3210 da Hitachi após 10 min da adição da água oxigenada a $25^{\circ} \mathrm{C}$. A atividade da peroxidase foi expressa em $470 / \mathrm{min}$ por g/PMF.

\section{RESULTADOS E DISCUSSÃO}

Efeito de BAP - É ampla a aplicação de citocininas na micropropagação, sendo associado os altos níveis de BAP à morfogênese anormal (ZIV, 1991). No entanto, os resultados demonstraram que mesmo baixos niveis de BAP promoveram alto índice de vitrificação. A partir da mais baixa concentração

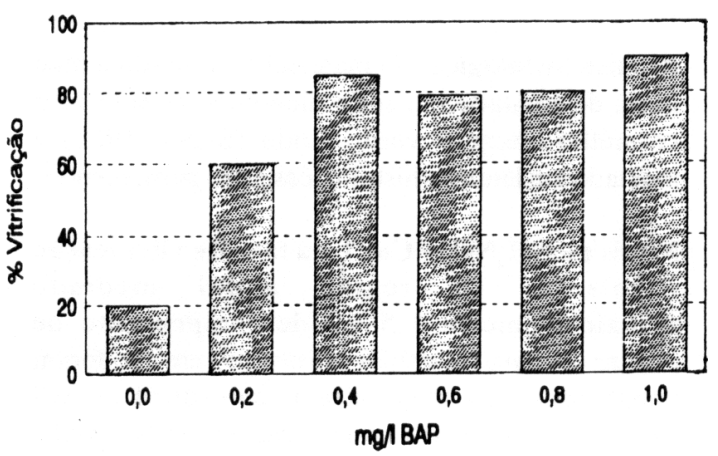

Figura 1 - Efeito de BAP no controle da vitrificação de ápices meristemáticos de $D$. caryophyllus in vitro aos $\mathbf{4 0}$ dias da inoculação. de BAP, $60 \%$ e $50 \%$ das plantas desenvolveram a vitrificação para a regeneração de ápices meristemáticos e multiplicação a partir de nódulos caulinares, respectivamente, aumentando essa taxa progressivamente com o aumento da concentração de BAP (Figuras 1 e 2). Mesmo no controle desenvolveram-se plantas vitrificadas, embora com baixa freqüència $(20 \%)$, sugerindo que outros fatores além do regulador BAP, estejam envolvidos na morfogênese anormal.

Por outro lado, doses elevadas de BAP garantiram rápido desenvolvimento e maior taxa de multiplicação de gemas. Todavia, no cultivo de ápices meristemáticos, somente o controle diferiu dos demais tratamentos. Embora baixos níveis de

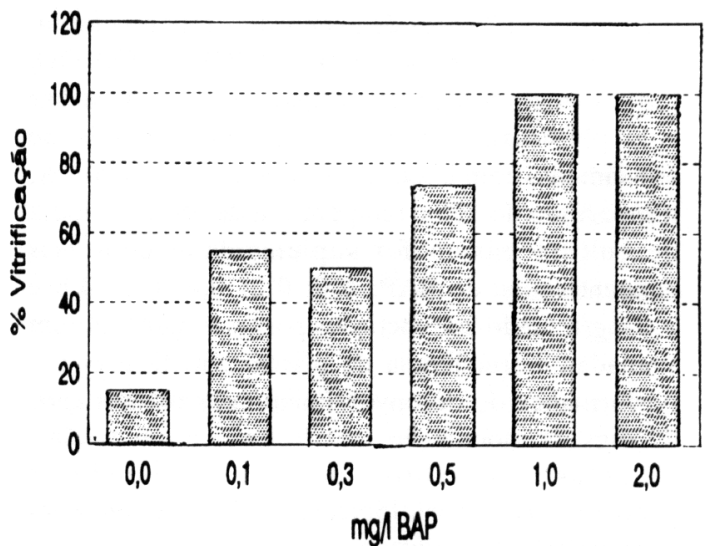

Figura 2 - Efeito de BAP no controle da vitrificação da fase de multiplicação de $D$. caryophyllus in vitro aos $\mathbf{4 0}$ dias da inoculação.

BAP tenham contribuído também para a redução da vitrificação durante a fase de multiplicação, ainda que fracamente, observou-se que as doses maiores ofereceram melhor taxa de perfilhamento com 16,5 brotações para a dose de 2,0 mg/l de BAP e 1,35 brotações para o controle (Figura 3). No entanto às taxas de perfilhamento seguiu-se redução no comprimento das brotações.

O mecanismo de ação da citocinina no processo da vitrificação é pouco compreendido. Talvez ela induza uma súbita atividade celular (BORNMAN \& VOGELMANN, 1984; KATAEVA et al., 1991; WLLIAMS \& RAJI, 1991) e em um meio com alto potencial hídrico e/ou uma atmosfera de elevada umidade relativa no interior dos frascos, resultaria em novas células que logo se turgiriam. Certos autores como GASPAR et al. (1984) citam ainda a possibilidade dos reguladores provocarem 


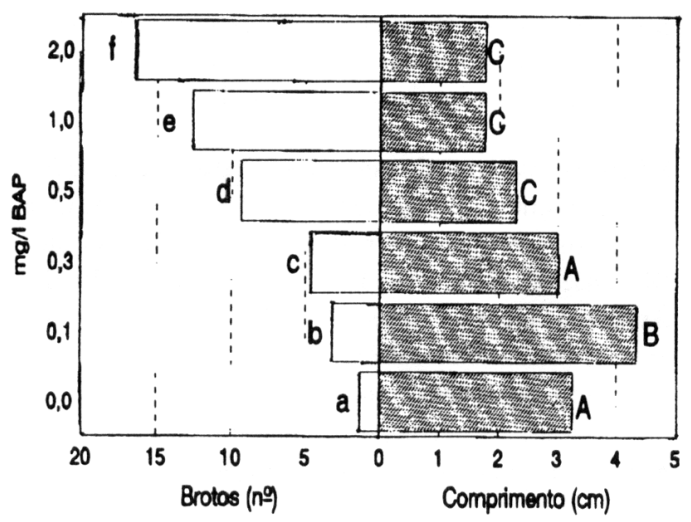

Figura 3 - Efeito de BAP na fase de multiplicação de $D$. caryophyllus in vitro aos $\mathbf{4 0}$ dias da inoculação.

um estresse com o posterior desencadeamento da sintese de etileno. Este último seria o responsável pelas alterações observadas na morfogênese anormal ao nível de parede celular.

Efeito de agente gelificante - Com o aumento da concentração do agente gelificante foi verificado uma sensível redução na vitrificação, embora resultando numa menor taxa de multiplicação e

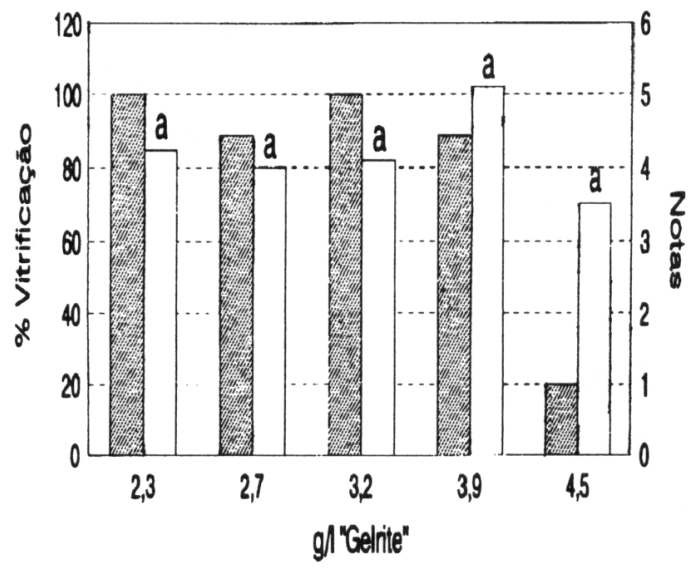

Figura 4 - Efeito de "Gelrite" no controle da vitrificação e do desenvolvimento de ápices meristemáticos de D. caryophyllus in vitro aos $\mathbf{4 0}$ dias da inoculação. Letras distintas diferem pelo teste de Tukey $(\mathrm{P}<.05 \%)$.

baixo desenvolvimento. Para o cultivo de ápices meristemáticos somente a concentração de $4,5 \mathrm{~g} / 1$ de "Gelrite" foi eficiente no controle da vitrificação sem afetar o desenvolvimento das plantas (Figura 4). Verificou-se na fase de multiplicação, uma relação proporcional entre nível de "Gelrite" e índice de vitrificação (Figura 5) que decaiu de $80 \%$ na menor concentração testada de $2,5 \mathrm{~g} / 1$ para $8,4 \%$ na maior concentração de $9,0 \mathrm{~g} / 1$. Por outro lado, maiores concentrações de "Gelrite" comprometeram a taxa de multiplicação e comprimento das brotações onde a dose de $2,5 \mathrm{~g} /$ 1 de "Gelrite" proporcionou melhor taxa de propagação com 10,2 gemas por explante (Figura 6) porém com $80 \%$ de vitrificação, enquanto na dose de $9,0 \mathrm{~g} / \mathrm{l}$ essa taxa decaiu para 4,2 gemas por explante, contudo com menor índice de vitrificação $(8,4 \%)$.

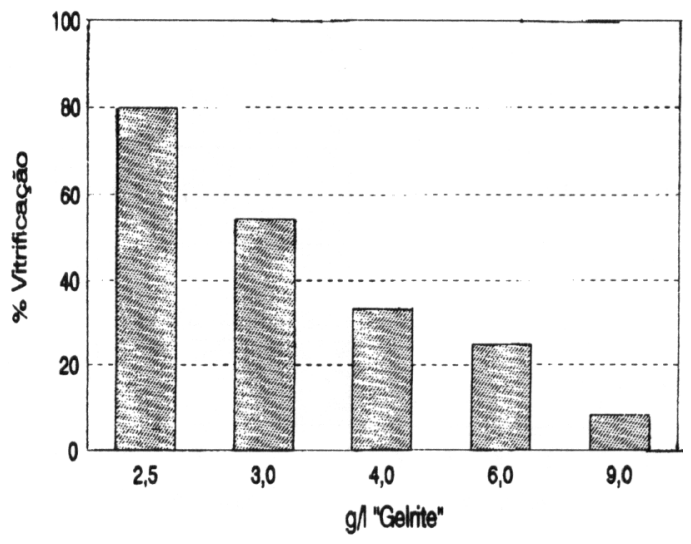

Figura 5 - Efeito de "Gelrite" no controle da vitrificação da fase de multiplicação de D. caryophyllus in vitro aos $\mathbf{4 0}$ dias da inoculação.

Resultados similares foram obtidos por PASQUALETO et al.,(1988) no controle da vitrificação elevando a concentração de "Gelrite" para 6,0 g/l; e por DEBERGH et al. 1981), ZIV et al. (1983) e CHOUDHARY (1991) aumentando a concentração de ágar para $11 \mathrm{~g} / 1$, porém a esse tratamento seguiu-se também considerável redução na taxa de propagação e no comprimento das brotações. Esses resultados podem ser atribuídos à condição de baixo potencial de água (ø) que afeta a disponibilidade de água e substâncias do meio de cultivo, dentre elas a citocinina (DEBERGH, 1983 e DEBERGH et al., 1981) que demonstrou ser potente estimulante da vitrificação nas condições do experimento.

As medições do potencial de água do meio básico nas variadas concentrações de "Gelrite" durante a multiplicação e em explantes 
foliares e caulinares de plantas normais e vitrificadas são apresentadas na Tabela 1 . Nota-se uma diminuição do (ø) em relação ao aumento da concentração do "Gelrite" obedecendo uma relação inversamente proporcional. A Tabela 1 mostra também que plantas vitrificadas apresentaram maior conteúdo de água em relação às plantas normais. Os valores do (ø) nas folhas e caules foram maiores nas plantas vitrificadas. Segundo KEVERS \& GASPAR (1985a,b), plantas vitrificadas são caracterizadas por desenvolverem baixa resistência de parede, permitindo intensa entrada de água a partir do meio com elevado (ø), gerando células

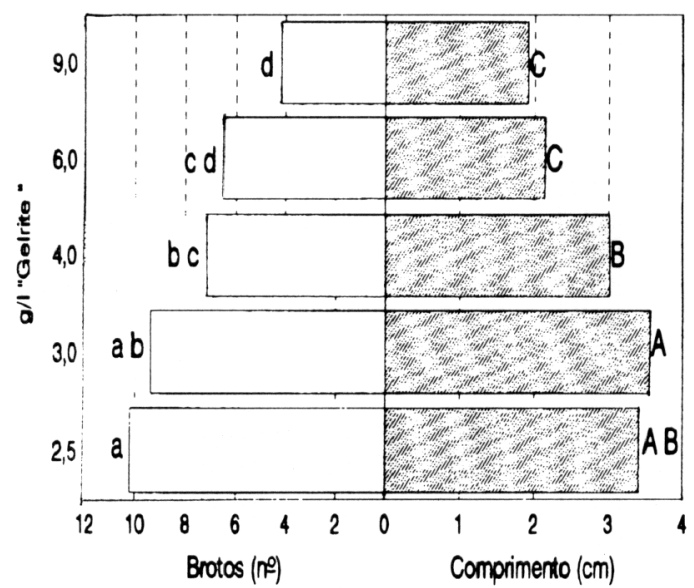

Figura6 -Efeito de "Gelrite" na fase de multiplicação da micropropagação de $D$. caryophyllus in vitro aos 40 dias da inoculação. Letras distintas diferem pelo teste de Tukey $(\mathrm{P}<.05 \%)$.

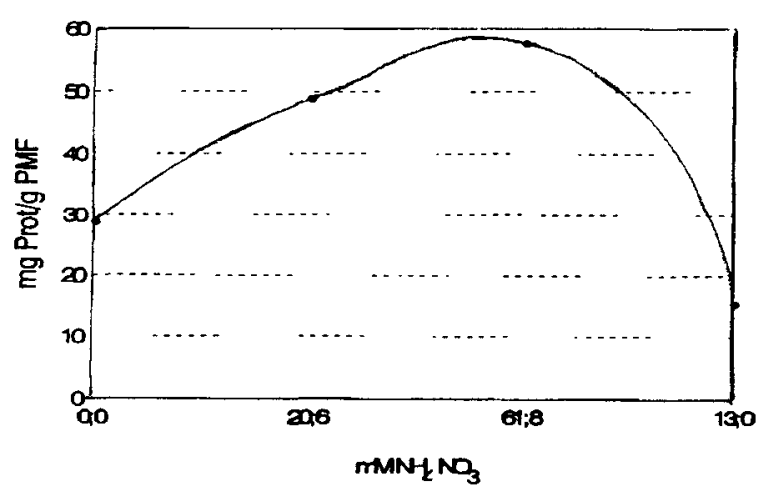

Figura 8A - Efeito do $\mathrm{N}_{4} \mathrm{H} \mathrm{N}_{3} \mathrm{O}$ no nível de proteínas de D. caryophyllus propagadas in vitro aos 30 dias de inoculação. hiper-hídricas. Nessas condições os meios de cultura com mais elevados potenciais de água estimularam maior índice de vitrificação.

Efeito de sistemas de vedação - Praticamente todos os tratamentos que acarretam redução da unidade contribuem para a redução da vitrificação (KATAEVA et al., 1991; RITCHIE et al., 1991). As combinações "tipos de vedação" e "nível de ágar" contribuíram satisfatoriamente na redução da vitrificação. $\mathrm{Na}$ regeneração de ápices meristemáticos, vedação com tampas de algodão reduziu a freqüência da vitrificação em ambas as

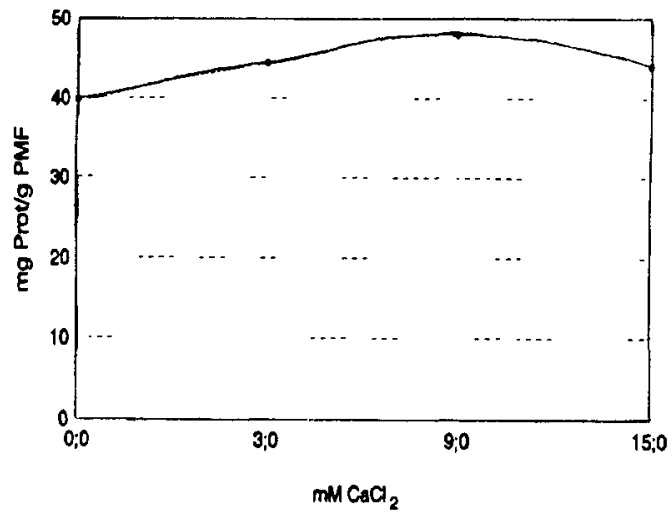

Figura 8B - Efeito do $\mathrm{CaCl}_{2}$ no nivel de proteínas de D. caryophyllus propagadas in vitro aos 30 dias de inoculação.

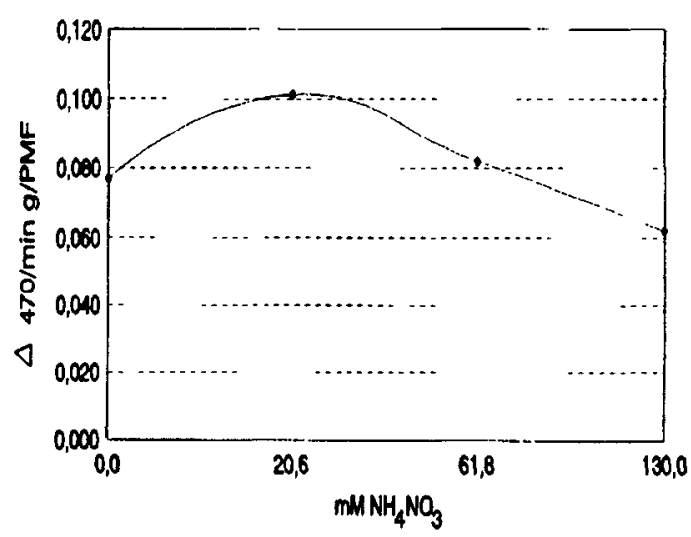

Figura 9A - Efeito do $\mathrm{NH}_{4} \mathrm{NO}_{3}$ na atividade da enzima peroxidase em plântulas de D. caryophyllus cultivadas in vitro aos 30 dias da inoculação. 


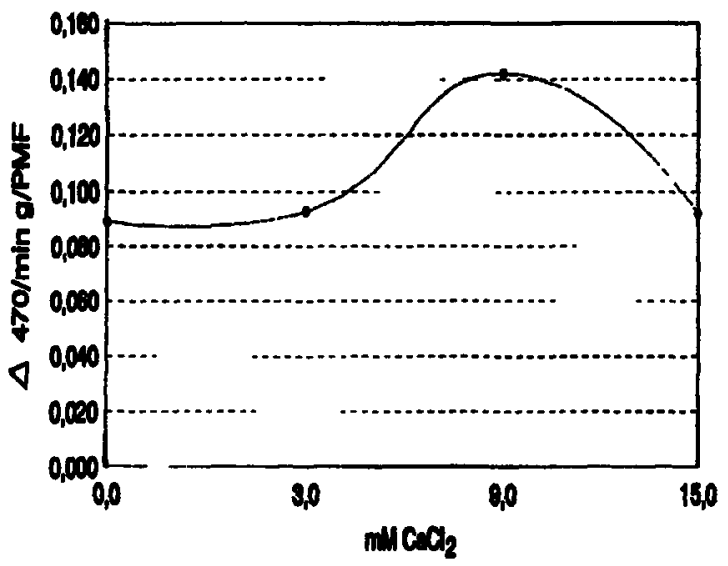

Figura 9B - Efeito do $\mathrm{CaCl}_{2}$ na atividade de enzima peroxidase em plantulas de $D$. caryophyllus cultivadas in vitro aos $\mathbf{3 0}$ dias da inoculação.

concentraçōes de ágar, no entanto, na concentração de $12 \mathrm{~g} / 1$ de agar verificou-se menor índice na vitrificação, comprometendo o desenvolvimento (Tabela 2).

O tipo de vedação e o tipo de substância gelificante afetaram a taxa de propagacão e o comprimento das brotaçöes. Sob as condições de tampas de algodão, a taxa de propagação foi $40 \%$ menor em relação d̀quelas plantas crescidas sob condição de papel alumínio e o comprimento decaiu $30 \%$. De igual modo, o ágar reduziu a taxa de propagação para $50 \%$ em relação ao uso de "Gelrite". HAKKAART \& VERSLUIJS (1983) também reduziram a vitrificação em cravo a níveis bastante significantes ao substituirem tampas de papel alumínio por tampas de algodão, 0 que implicou no baixo desenvolvimento das plantas. Esse efeito pode ser atribuido ds perdas de água no meio pela evaporação sob condiçōes de baixa umidade restringindo a disponibilidade de água e nutrientes do meio de cultura (DEBERGH et al., 1981).

Embora tenha sido verificado em alguns trabalhos um aumento de etileno em frascos selados, o seu papel na vitrificação 6 ainda obscuro. Segundo DEBERGH et al. (1981), a presença de etileno parece estar relacionada a uma reduçăo na lignificaçäo da parede celular. Assim, o tipo de vedação estaria envolvido na melhor aeraçüo, permitindo a eliminação do etileno para o meio externo e não na redução da umidade interna.

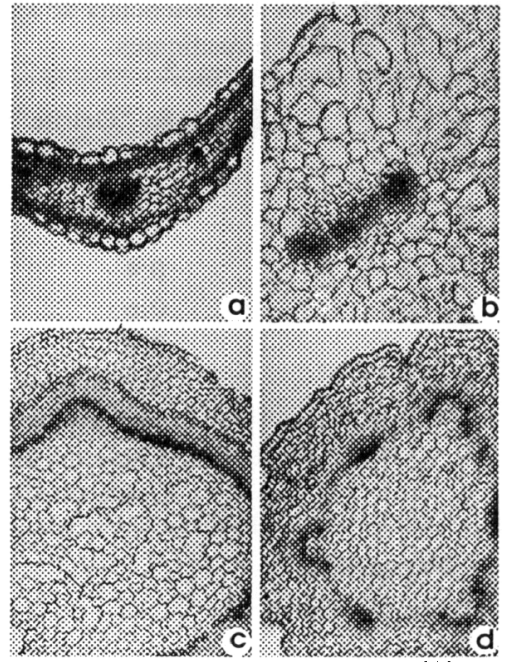

Figura 7 - Corte Transversal de Folha de Material Normal (A) e vitrificado (B), e Caule de Material Normal (C) e vitrificado (D) em aumento 100x.

Estudos anátomo-histológicos - Estudos da anatomia comparativa revelaram sensíveis alteraçōes na organização estrutural do meśffilo e dos tecidos caulinares do material normal e vitrificado como está evidenciado na Figura 7. De imediato percebe-se que a nítida distribuição ordenada, característica dos tecidos parenquimatosos e dos condutores e da epiderme da folha de planta normal (Figura 7A) dá lugar a um padrão morfogenético assinalado pelo alto grau de desorganização do parenquima ao longo do mes6filo, dotado de celulas volumosas e alongadas, com um acréscimo de grandes espaços intercelulares em folhas de plantas vitrificadas (Figura 7B), causando a impressão de um arranjo paliçadico, inexistente em folhas não vitrificadas do cravo. Este arranjo caracteriza uma enorme alteração na relação nucleoplasmática (RNP), evidenciando um maior volume citoplasmático superior ao esperado para este tecido em material normal.

No material em estudo percebe-se também a redução dos tecidos condutores limitados a estreitos feixes vasculares. GERSANI et al. (1986) atribuíram a ausência de dominlncia apical cm plantas vitrificadas a redução dos tecidos vasculares por onde se daria, preferencialmente, o transporte de auxinas. Esta baixa capacidade de diferenciação 
TABELA 1 - Medidas dos potenciais de água (ø) em diferentes concentrações de "Gelrite"e em explantes foliares e caulinares.

\begin{tabular}{|c|c|}
\hline Condição "Gelrite" \% & $\varpi(\mathrm{MPa})$ \\
\hline 0,25 & $-0,36$ \\
\hline 0,3 & $-0,42$ \\
\hline 0,4 & $-0,5$ \\
\hline 0,6 & $-0,69$ \\
\hline 0,9 & $-1,5$ \\
\hline Folha normal & $-1,7$ \\
\hline Folha vitrificada & $-0,75$ \\
\hline Caule normal & $-1,4$ \\
\hline Caule vitrificado & $-0,9$ \\
\hline
\end{tabular}

$M P a=$ Megapascal

TABELA 2 - Médias das notas e número de plantas vitrificadas de ápices meristemáticos de cravo, considerando o tipo de vedação e concentrações de ágar.

\begin{tabular}{ccccc}
\hline \hline Tratamentos & \multicolumn{3}{c}{ R. L. de Plantas } \\
g/l ágar & Vedação & Notas & Vitrificadas \\
8 & alumínio & $3,20 \mathrm{Aa}$ & 0,700 \\
8 & algodão & $4,00 \mathrm{Aa}$ & 0,200 \\
12 & alumínio & $4,00 \mathrm{Aa}$ & 0,500 \\
12 & algodão & $2,00 \mathrm{Bb}$ & 0,100 \\
C.V $(\%)$ & 43,66 & R.L. ns & \\
\hline \hline
\end{tabular}

Letras distintas diferem pelo teste de Tukey $(\mathrm{P}<.05-$ maiúsculas e $\mathrm{P}<.01$ - minúsculas) de probabilidade. Regressão linear (R.L. ns) não significativa com $P<.01 \%$.

TABELA 3 - Médias de plantas vitrificadas durante a multiplicação de gemas de cravo considerando diferentes doses de $\mathrm{NH}_{4} \mathrm{NO}_{3}$ e $\mathrm{CaCl}_{2}$.

\begin{tabular}{lcl}
\hline \hline & Tratamentos (mM) & Vitrificação \\
& 0,0 & 0,1410 \\
$\mathrm{NH}_{4} \mathrm{NO}_{3}$ & 20,6 & 0,1924 \\
& 61,8 & 0,334 \\
& 130,0 & 0,6325 \\
$\mathrm{CaCl}_{2}$ & 0,0 & 0,4780 \\
& 3,0 & 0,4187 \\
& 9,0 & 0,3081 \\
& 15,0 & 0,0952 \\
\hline \hline
\end{tabular}

Regressão linear (R.L. *) significativa com $P<.05 \%$. 
dos tecidos vasculares ainda não está bem escla recido.

As mesmas alterações observadas em folhas vitrificadas, de igual modo, se aplicam em caules vitrificados, caracterizados histologicamente por células tipicamente volumosas e de contorno irregular no córtex, apresentando grandes espaços intercelulares e tecidos vasculares reduzidos, limitados a pequenos feixes (Figura 7D), enquanto em caule de plantas normais os tecidos vasculares estão em disposição concêntrica e contínua (Figura 7C). Desordens nos tecidos vasculares, clorofilianos e de sustentação são citadas como o efeito mais pronunciado em diversas espécies suscetíveis à vitrificação como Castanea sativa (VIEITEZ et al., 1985), Dianthus caryophyllus (WERKER \& LESHEM, 1987) e maçã. Neste trabalho nenhuma alteração foi encontrada na epiderme caulinar.

\section{Níveis de $\mathrm{NH}_{4} \mathrm{NO}_{3}$ e CaCl, na taxa de vitrificação}

- Elevados níveis de amônia provaram ser um forte aliado na promoção da vitrificação em diversas espécies estudadas (ZIV, 1991). Relação inversa foi constatada por GASPAR et al. (1984) em meios enriquecidos de cálcio para certas espécies lenhosas. Tais informações corroboram os resultados do presente trabalho no qual a frequeência da vitrificação elevou-se progressivamente de acordo com o aumento dos níveis de $\mathrm{NH}_{4} \mathrm{NO}_{3}$ (Tabela 3).

Da mesma forma ZIV et al. (1987) aumentaram a proporção de plantas normais em cultura de crisântemo reduzindo os níveis de nitrato de amônio ou eliminando-o completamente do meio MS. Uma tendência inversa com os tratamentos de cálcio está evidenciado na Tabela 3 onde a dose máxima de $15,0 \mathrm{mM}$ eliminou parcialmente a vitrificação, enquanto a total ausência de $\mathrm{CaCl}_{2}$ elevou este indice para $50 \%$. Há também a possibilidade de se reduzir a vitrificação aumentando os níveis de cálcio no meio (ZIV, 1991). As análises determinaram ainda, o melhor tratamento no controle da vitrificação como sendo a eliminação total do amônio, onde a vitrificação decaiu de $60 \%$ na dose de $130,0 \mathrm{mM}$ para $10 \%$ com a eliminação total do amônio. DAGUIN \& LETOUZÉ (1987) e LEONHARDT \& KANDELER (1987) observaram um aumento na lignificação da parede celular de ameixa e cactos diminuindo o nível de amônio. Para os níveis de cálcio os resultados demonstraram que a dose de $15,0 \mathrm{mM}$ de $\mathrm{CaCl}_{2}$ pode ser considerada
- melhor tratamento no combate à vitrificação (Tabela 3).

Proteína total solúvel - Ainda que a eliminação total do amônio tenha proporcionado os mais baixos índices de vitrificação (10\%), este tratamento afetou o desenvolvimento das plantas devido ao decréscimo do nível de proteína (Figura 8A). Por outro lado para os tratamentos de cálcio, a maior dose testada, que resultou na máxima redução da vitrificação, não afetou drasticamente o desenvolvimento das plantas em função da leve queda do nível de proteína (Figura 8B). Os tratamentos de amônio e de cálcio determinaram um aumento gradual no teor de proteína, no entanto, os níveis alcançados com $\mathrm{NH}_{4} \mathrm{NO}_{3}$ foram superiores aos de $\mathrm{CaCl}_{2}$ (Figuras 8A e B).

Análise bioquímicas revelaram que o conteúdo de proteínas em plantas vitrificadas ć superior ao das plantas normais (LETOUZÉ \& DAGUIN, 1983; PHAN \& LETOUZÉ, 1983 ; ZIV et al., 1983). LETOUZÉ \& DAGUIN (1983), VIETH et al. (1983) e KEVERS et al. (1984) sugerem que a alta concentração de amônio pode levar a um aumento na taxa $\mathrm{C} / \mathrm{N}$ devido a maior atividade das vias biossintéticas de aminoácidos, ocasionando uma queda na atividade da via das pentoses, fonte de componentes estruturais da parede celular como a lignina e a celulose.

Confirmando essas observações temse constatado uma relação entre aumento da vitrificação e atividade da glutamato desidrogenase, ocasionada pelas elevadas concentrações amoniacais do meio (DAGUIN \& LETOUZÉ, 1987). Embora o cálcio tenha estimulado também a síntese de proteína ainda que em níveis sempre inferiores aos tratamentos de amônio, salvo a última dose, esse aumento de proteína nos tratamentos com cálcio não foi acompanhado pelo aumento da vitrificação como foi observado para os tratamentos com amônio.

Esse comportamento está ligado ao fato de que o cálcio age como cofator da peroxidase, enzima chave do metabolismo da parede celular, que promove ligações entre seus polímeros dando firmeza e limitando o alongamento da parede celular por ocasião da entrada da água no citoplasma celular. Desse modo, o aumento da síntese de proteína nos tratamentos de cálcio não foi seguido pela vitrificação, pois os altos níveis de cálcio compensariam, atuando diretamente no 
metabolismo da parede celular, impedindo a baixa resistência da parede característica de células de material vitrificado.

Atividade da peroxidase - Enquanto doses crescentes de amônio revelaram-se inibitórias na atividade da peroxidase (Figura $8 \mathrm{~A}$ ), efeito inverso foi notado para as doses de cálcio, salvo a última dose onde se observou uma pronunciada queda na atividade desta enzima (Figura 8B). De acordo com DAVIES (1990), a peroxidase age realizando ligações do tipo isoditirosil entre proteínas de parede, e do tipo difurilato entre polissacarídeos de parede, restringindo a plasticidade da parede celular. Portanto, tratamentos estimuladores da atividade de peroxidase podem controlar a vitrificação como constatado no presente trabalho. Além de estimular a atividade da peroxidase, 0 cálcio pode se acumular na lamela média na forma de pectato de cálcio e promover ligações entre as microfibrilas da parede celular através de pontes de cálcio, limitando a extensibilidade da parede. Por isso, não se observou um aumento na taxa de vitrificação à maior dose $\mathrm{de} \mathrm{CaCl}_{2}$ por ocasião da queda da atividade da peroxidase nesta última dose.

Esperava-se que a cinética enzimática fosse linear ao longo dos tratamentos, porém, para a maior dose de cálcio onde $90 \%$ das plantas desenvolveram-se sem vitrificação, ocorreu uma sensível queda na atividade da peroxidase.

De acordo com MALAVOLTA (1980), elevados níveis de cálcio podem inibir a absorção de outros íons como o magnésio numa relação antagônica. Por excelência, o magnésio é considerado um importante cofator enzimático de expressiva participação nas vias metabólicas primárias cruciais do desenvolvimento vegetal como a glicólise, Ciclo de Krebs e a vida das pentoses. Assim, a maior dose de cálcio poderia ter inibido a absorção do $\mathrm{Mg}$ e o déficit desse elemento ter reduzido a atividade do Ciclo de Krebs que além de ser fonte de energia, tem ainda a função de fornecer precursores para a biossíntese de proteínas, incluindo ai, a peroxidase. Mesmo assim a baixa atividade da peroxidase na dose de $15,0 \mathrm{mM}$ de $\mathrm{CaCl}_{2}$ não promoveu a vitrificação, uma vez que 0 elevado nível de cálcio, possivelmente continuou contribuindo para a formação de pectato de cálcio na lamela média e ligações entre as microfibrilas da parede através de pontes de cálcio, limitando a extensibilidade da parede celular.
Se bem que o possível déficit de $\mathbf{M g}$ na maior dose de cálcio pudesse afetar a biossíntese de proteínas, maior dreno da glicose-6-P poderia ser direcionado, preferencialmente à via das pentoses, para a biossíntese de precursores de celulose e lignina. Segundo KEVERS et al. (1984) e VIEITEZ et. al. (1985), o baixo nível de celulose e lignina são as maiores causas da vitrificação. Nas doses elevadas de amônio, a baixa atividade da peroxidase pode ser atribuída à retro-inibição da síntese proteica e conseqũentemente da peroxidase. Mesmo que este efeito favoreça maior atividade da via das pentoses, a baixa atividade da peroxidase constatada seria ineficiente para realizar as ligações das microfibrilas disponíveis.

\section{CONCLUSÃO}

Os resultados obtidos nas condições deste trabalho, permitem concluir que o baixos níveis do regulador BAP, gel do tipo ágar, baixa umidade nos frascos e baixos potenciais de água podem reduzir consideravelmente a vitrificação, comprometendo, entretanto, a taxa de propagação e crescimento das plântulas. Fatores nutricionais como baixos níveis amoniacal e elevados níveis de cálcio, demonstraram ser inibitórios da vitrificação. As alterações celulares observadas parecem estar sob ação direta da peroxidase e tratamentos que estimulam a sua atividade deve contornar $o$ problema.

Deste modo, os resultados permitiram estabelecer um protocolo para a micropropagação do cravo, para controle da vitrificação, constituído de $4,5 \mathrm{~g} / \mathrm{l}$ de "Gelrite" ou $8 \mathrm{~g} / \mathrm{l}$ de ágar, $0,5 \mathrm{mg} / \mathrm{l}$ de ANA, $0,05 \mathrm{mg} / 1$ de BAP, doses normais das soluções salinas do meio MS e vedação do tipo tampas de algodão para cultura de ápices meristemáticos. Para a fase de multiplicação, este protocolo deve ser alterado para $0,5 \mathrm{mg} / \mathrm{l}$ de BAP, $10,3 \mathrm{mM} \mathrm{deNH}_{4} \mathrm{NO}_{3}$ e $12 \mathrm{mM}$ de $\mathrm{CaCl}_{2}$ do meio básico de MS.

\section{REFERÊNCIAS BIBLIOGRÁFICAS}

BORNMAN, C.H. \& VOGELMANN, T. Effect of rigidity of gel medium on benzyladenine - induced adventitious bud formation and vitrification in vitro in Picea abis. Physiologia Plantarum, Copenhagen, v.61, p.505-512, 1984. 
CHOUDHARY, M.L. Vegetative propagation of carnation in vitro through multiple shoot development. Indian Journal of Horticulture, Bangalore, v.48, p.177-181, 1991.

DAGUIN, F, \& LETOUZE, R. Ammonium-induced vitrification in cultured tissues. Physiologia Plantarum, Copenhagen, v.66, p.94-98, 1986.

DAGUIN, F. \& LETOUZE, R. Vitreous plants in vitro: relationship with ammonium content of the nutrient medium. Acta Horticulturae, The Hague, v.212, p.259-261, 1987.

DAVIES, P.J. The plant hormones: their nature, occurence and functions. In:, ed. Plant hormones and their role in plant growth and development. New York: Kluwer Academic, 1990. p.1-11.

DEBERGH, P.C. Effects of agar brand and concentration on the tissue culture medium. Physiologia Plantarum, Copenhagen, v.59, p.270-276, 1983.

DEBERGH, P.C.; HARBAOURI, Y.; LEMEUR, R. Mass propagation of globe artichocke (Cynara scolymus): evaluation of different hypotheses to overcome vitrification with special reference to water potential. Physiologia Plantarum, Copenhagen, v.53, p.181$187,1981$.

FERHRMANN, H.; DIMOND, A.E. Peroxidase activity and phytopthora resistance in different organs of the potato plant. Phytopathology, Lancaster, v.57, p.69$72,1967$.

GERSANI, M.; LESHEM, B.; SACHS, T. Impaired polarity in abnormal plant development. Journal of Plant Physiology, Stuttgart, v.123, p.91-95, 1986.

GASPAR, T.; KEVERS, C.; DEBERGH, P.; MAENE, L.; PASQUES M.; BOXUS, P. Vitrification: morphological, physiological and ecological aspects. In: BONG, J.M. \& DURZAN, D.J., ed, Cell and tissue culture in forestry. Dordrecht: Martinus Nijhoff, 1984. v.1, p. 152-166

HAKKAART, F.A.; VERSLUIJS, J.A.A. Some factors affecting glassiness in carnation meristem tip cultures. Netherlands Journal of Pathology, Wageningen, v.89, p.47-53, 1983.

KATAEVA, N.V.; ALEXANDROVA, I.G.; BUTENKO, R.G.; DRAGAVTCEVA, E.F. Effect of applied an internal hormones on vitrification and apical necrosis of different plants cultured in vitro. Plant Cell, Tissue and Organ Culture, The Hague, v.27, n.2, p.149$154,1991$.
KEVERS, C. \& GASPAR, T. Soluble, membrane and wall peroxidases, phenylalanine ammonia-lyase, and lignin changes in relation to vitrification of carnation tissues cultured in vitro. Joumal of Pant Physiology, Stuttigart, v.118, p.41-48, 1985a.

KEVERS, C. \& GASPAR, T. Vitrification of carnation in vitro: changes in ethylene production, $A C C$ level and capacity to convert ACC to ethylene. Plant Cell, Tissue and Organ Culture, The Hague, v.4, p.215-223, $1985 b$.

KEVERS, C. \& GASPAR, T. Vitrification of carnation in vitro: changes in water content, extracellular space, air volume, and ion levels. Physiologie Vegetale, Paris, v.24, n.6, p.647-653, 1986.

KEVERS, C.; COUMANS, M.; COUMANS-GILLES, F.; GASPAR, T. Physiological and biochemical events leading to vitrification of plants cultured in vitro. Physiologia Plantarum, Copenhagen, v.61, p.69-74, 1984.

KEVERS, C.; PRAT, R.; GASPAR, T. Vitrification of carnation in vitro: changes in cell wall mechanical properties, cellulose and lignin content. Plant Growth Regulation, The Hage, v.5, p.59-66, 1987.

LEONHARDT, W. \& KANDELER, R. Ethylene accumulation in culture vessels - a reason for vitrification? Acta Horticulturae, The Hague, v.212, p.223239, 1987.

LESHEM, B.; SHALEV, D.P., IZHAR, S. Cytokinin as an inducer of vitrification in melon. Annals of Botany, London, v.61, p.255-260, 1988a.

LESHEM, B.; WERKER, E.; SHALEV, D.P. The effect of cytokinins on vitrification in melon and carnation. Annals of Botany, London, v.62, p.271-276, $1988 \mathrm{~b}$.

LETOUZE, R. \& DAGUIN, F. Manifestation spontanee et aléatoire d'une croissance anormale en culture in vitro. Recherche de marqueurs metaboliques. Revue Canadiense Biologie Experimentale, Montreal, v.42, p.23-28, 1983.

LOWRY, O.H.; ROSEBROUGH, N.J.; FAR, A.A.; RANDAL, R.J. Protein measurement with the folin phenol reagent. Journal of Biological Chemistry, Colchester, v.193, p.265-275, 1951.

MALAVOLTA, E. Dementos de nutrição mineral de plantas. São Paulo: Agnonômica Ceres, 1980. 251p. 
MURASHIGE, T. \& SKOOG, F. A revised medium for rapid growth and bioassays with tobacco tissue culture. Physiologia Plantarum, Copenhagen, v.15, p.473-497, 1962.

PASQUALETO, P.L.; ZIMMERMANN, R.H.; FORDHAM, I. The influence of cation and gelling agent concentration on vitrification of apple cultivars in vitro. Plant Cell and Organ Culture, The Hague, v.14, p.31-40, 1988.

PHAN, C.T. \& LETOUZÉ, R. A comparative study of chlorophyll, phenolic and protein contents and of hydroxycinnamate: Coa ligase activity of normal and vitreous plants (Prunus avium L.) obtained in vitro. Plant Science Letters, Limerick, v.31, p.323-327, 1983.

RITCHIE, G.A.; SHORT, K.C.; DAVEY, M.R. In vitro acclimatization of crhysanthemun and sugar beet plantlets by treatment with paclobutrazol and exposure to reduced humidity. Joumal of Experimental Botany, Oxford, v.42, n.245, p.157-163, 1991.

SASS, J.E. Botanical microtechnique. 2.ed. Ames: Iowa State Colege Press, 1951.228p.

SUTTER, E.G.; LANNGHANS, R.W. Epicuticular formation on carnation plantlets regenerated from shoot tip culture. Joumal of the American Society for Horticultural Science, St. Joseph, v.104, n.4, p.493-496, 1979.

VIEITEZ, A.M.; BALLESTER, A.L.; SAN-JOSE, M.C.; VIEITEZ, E. Anatomical and chemical studies of vitrified shoots of chestnoot regenerated in vitro. Physiologia Plantarum, Copenhagen, v.65, p.177184, 1985.
VIETH, J.; MORISSET, C.; LAMAND, M. Histologie de plantules vitreuses de Pyrus malus cv. M-26 et de Pelargonium peltatum cv. Chester Frank, tissues de la culture in vitro (Etudes préliminaires). Revue Canadiense Biologie Experimentale, Montreal, v.42, p.29-32, 1983.

WERKER, E.; LESHEM, B. Structural changes during vitrification of carnation plantlets. Annals of Botany, London, v.59, p.377-385, 1987.

WILLIAMS, R.R. \& RAI, A.M. Effect of temperature, gel concentration and cytokinins on vitrification of Olearia micnodisca (j.M. black) in vitro shoot cultures. Plant Cell, Tissue and Organ Culture, The Hague, v.26, n.1, p.1-6, 1991.

ZIV, M. Vitrification: morphological and physiological disorders of in vitro plants. In: DEBERGH, P.C.; ZIMMMERMMAN, R.H., ed. Micropropagation: technology and application. Dordrecht: Kluwer Academic, 1991 cap. 4 , p.45-69.

ZIV, M. MEIR, G. \& HALEVY, A.H. Factors influencing the production or hardened glaucous carnation plantlets in vitro. Plant Cell, Tissue and Organ Culture, The Hague, v.2, n.1, p.55-60, 1983.

ZIV, M.; SCHWARTZ, A.; FLEMINGER, D. Malfuctioning stomata in vitreous leaves of carnation (Dianthus caryophyllus) plants propagated in vitro; implications for hardening. Plant Science, Lucknow, v. 52, p.127-134, 1987.

Recebido para publicação em 21.06.94 Aceito para publicação em 10.10.95 